\title{
Influence of Dose Rate on the Cellular Response to Low- and High-LET Radiations
}

\author{
Anne-Sophie Wozny ${ }^{1,2}$, Gersende Alphonse ${ }^{1,2}$, Priscillia Battiston-Montagne ${ }^{1}$, \\ Stéphanie Simonet ${ }^{1}$, Delphine Poncet ${ }^{1,2}$, Etienne Testa ${ }^{3}$, Jean-Baptiste Guy ${ }^{1,4}$, \\ Chloé Rancoule ${ }^{4}$, Nicolas Magné ${ }^{1,4}$, Michael Beuve ${ }^{3+}$ and Claire Rodriguez-Lafrasse ${ }^{1,2 * t}$ \\ 1 UMR/CNRS 5822, Laboratoire de Radiobiologie Cellulaire et Moléculaire, Université Claude Bernard Lyon 1, Oullins, France, \\ ${ }^{2}$ Centre Hospitalier Lyon-Sud, Hospices-Civils-de-Lyon, Pierre-Bénite, France, ${ }^{3} I P N L-L I R I S-C N R S-I N 2 P 3$, Villeurbanne, \\ France, ${ }^{4}$ Département de Radiothérapie, Institut de Cancérologie de la Loire Lucien Neuwirth, St-Priest-en-Jarez, France
}

OPEN ACCESS

Edited by:

John Varlotto,

University of Massachusetts Medical

Center, USA

Reviewed by:

Evagelia C. Laiakis,

Georgetown University, USA

John Eley,

University of Maryland School of

Medicine, USA

*Correspondence:

Claire Rodriguez-Lafrasse claire.rodriguez-lafrasse@univ-lyon1.fr

'Michael Beuve and Claire RodriguezLafrasse contributed equally to this work and should be considered as joint last authors.

Specialty section:

This article was submitted to Radiation Oncology, a section of the journal

Frontiers in Oncology

Received: 04 January 2016

Accepted: 28 February 2016

Published: 14 March 2016

Citation:

Wozny A-S, Alphonse G, BattistonMontagne $P$, Simonet $S$, Poncet $D$,

Testa E, Guy J-B, Rancoule C, Magné N, Beuve M and Rodriguez-

Lafrasse C (2016) Influence of Dose

Rate on the Cellular Response to Low- and High-LET Radiations.

Front. Oncol. 6:58. doi: 10.3389/fonc.2016.00058
Nowadays, head and neck squamous cell carcinoma (HNSCC) treatment failure is mostly explained by locoregional progression or intrinsic radioresistance. Radiotherapy (RT) has recently evolved with the emergence of heavy ion radiations or new fractionation schemes of photon therapy, which modify the dose rate of treatment delivery. The aim of the present study was then to evaluate the in vitro influence of a dose rate variation during conventional RT or carbon ion hadrontherapy treatment in order to improve the therapeutic care of patient. In this regard, two HNSCC cell lines were irradiated with photons or $72 \mathrm{MeV} / \mathrm{n}$ carbon ions at a dose rate of 0.5 , 2, or $10 \mathrm{~Gy} / \mathrm{min}$. For both radiosensitive and radioresistant cells, the change in dose rate significantly affected cell survival in response to photon exposure. This variation of radiosensitivity was associated with the number of initial and residual DNA double-strand breaks (DSBs). By contrast, the dose rate change did not affect neither cell survival nor the residual DNA DSBs after carbon ion irradiation. As a result, the relative biological efficiency at 10\% survival increased when the dose rate decreased. In conclusion, in the RT treatment of HNSCC, it is advised to remain very careful when modifying the classical schemes toward altered fractionation. At the opposite, as the dose rate does not seem to have any effects after carbon ion exposure, there is less need to adapt hadrontherapy treatment planning during active system irradiation.

Keywords: high- and low-LET irradiations, carbon ions, photons, dose rate, DNA double-strand breaks, head and neck squamous cell carcinoma

\section{INTRODUCTION}

Head and neck cancer is the sixth most common type of cancer worldwide. More than 600,000 new patients are diagnosed per year among which approximately 350,000 will die (1). Over $60 \%$ of patients present a locally advanced stage (III-IV) at diagnosis, and despite improvements in the therapeutic management of this type of cancer in recent years, disease-free survival at 3 years does not exceed $30 \%$ and overall survival at 5 years is less than $50 \%$ (2). Three major therapeutic strategies are used for non-operated stage III and IV squamous cell carcinoma: (1) combined radiotherapy (RT) and concomitant platin-based chemotherapy (CT), (2) concomitant association of RT with 
cetuximab (anti-EGFR), and (3) induction CT with a combination of docetaxel, cisplatin, and 5-fluorouracil (TPF) followed by $\mathrm{RT}$ alone (3). If high response rates are observed after TPF $\pm \mathrm{RT}$ (68 and $72 \%$, respectively), with 8.5 and $17 \%$ of complete response $(3,4)$, disease-free survival remains poor. Recurrences are mainly related to a locoregional progression ( 85 and $86 \%$ ), and this failure could be linked to an acquired or inherent radioresistance to low-LET radiation.

Improvements in RT over the last decade are linked to the emergence of intensity-modulated techniques and new protocols of altered fractionation, which modify the dose rate of treatment delivery or to the use of heavy ion species (5). Hyperfractionation shows improvements in survival of head and neck squamous cell carcinoma (HNSCC) patients (6) and hypofractionated schemes are efficient for palliation (7). However, limited biological data have up to now been published on the effect of a dose rate variation on the tumor survival. In parallel, hadrontherapy offers advantages over conventional RT due to the physical and biological properties of carbon ion irradiation, which have an enhanced radiobiological effectiveness (RBE) caused by the dense ionization, resulting in complex irreparable DNA lesions (8). Therefore, hadrontherapy is a very promising approach for treating radioresistant tumors located near organs at risk (9). However, carbon ions delivered by an active scanning system cause an important variation in the dose rate within the tumor volume. The deepest parts of the tumor are irradiated in less than $1 \mathrm{~s}$, whereas the shallowest parts of the tumor are irradiated in a few minutes. Moreover, modern techniques of photon radiation, such as intensity-modulated RT, may increase the number of radiation fields, and thus the dose is delivered to the tumor in a longer time. If cellular radiosensitivity is dose rate dependent after photon exposure, very little is known about high-LET radiation dose rate response.

The aim of this work was then to better understand the effects of doses' variations for high- and low-LET radiations on cancer cell lines in terms of radiosensitivity, cell survival, and DNA double-strand-breaks in order to better adapt the radio- and hadrontherapy treatment.

\section{MATERIALS AND METHODS}

\section{Cell Culture}

Two HNSCC cell lines were used. The radiosensitive SCC61 and the radioresistant SQ20B cell lines were grown, as previously described $(10,11)$.

\section{Irradiation Procedure}

Photon irradiations were performed on a $250-\mathrm{kV}$ irradiator (X-RAD 320, PXI), at the Lyon-Sud University (11) (UMS3444/ US8 platform, France), and carbon ion irradiations (72 MeV/n, LET $33.6 \mathrm{keV} / \mu \mathrm{m}$ ), at Grand Accélérateur National d'Ions Lourds (GANIL, Caen, France), facilities, as previously described $(12,13)$.

\section{Analysis of Clonogenic Cell Survival}

Cell survival following irradiation was quantified using a colony forming assay, as previously described $(12,14)$. Ten to sixteen hours before irradiation, SCC61 and SQ20B cells were seeded in $25 \mathrm{~cm}^{2}$ flasks at different densities, depending on the dose of radiation. Cells were irradiated at room temperature at 1,2,3,4, or 5 Gy delivered at a dose rate of $0.5,2$, or $10 \mathrm{~Gy} / \mathrm{min}$, respectively. For each dose and dose rate tested, six flasks were irradiated at two different cell densities. After irradiation, flasks were replaced in the incubator at $37^{\circ} \mathrm{C}$. After six cellular divisions, colonies were fixed with ethanol $95 \%$ and stained with Giemsa (1/20). The number of colonies containing at least 64 cells was counted using Coltcount (Optronix), and the surviving fractions were calculated using the formula $S(D)=n(D) / \mathrm{PE} \times N(D)$, where $n$ represents the number of colonies, $N$ the seeded cell number, and PE the plating efficiency. Each experiment was realized in triplicate.

\section{Immunocytochemistry - $\gamma \mathrm{H} 2 \mathrm{AX}$ Assay}

The method was adapted from Tanaka et al. (15). Cells were irradiated at 1 and 2 Gy with photons or carbon ions at a dose rate of $0.5,2$, or $10 \mathrm{~Gy} / \mathrm{min}$. At $15 \mathrm{~min}$ (only for photons), $30 \mathrm{~min}, 1,2$, and $24 \mathrm{~h}$ after irradiation, cells were trypsinized, washed with PBS, and fixed in $70 \%$ ice-cold ethanol for at least $24 \mathrm{~h}$. Cells were then resuspended in PBS for a wash and incubated in permeabilization buffer (20 mM HEPES, $50 \mathrm{mM} \mathrm{NaCl}, 3 \mathrm{mM} \mathrm{MgCl}$, $300 \mathrm{mM}$ sucrose, and $0.5 \%$ Triton X-100 in PBS). After two washes in PBSMB (PBS 1\% milk, 0.1\% BSA), cells were incubated for $2 \mathrm{~h}$ with gentle agitation in a primary antibody solution consisting of an antiphospho-histone-H2AX (serine139) mouse monoclonal IgG1 antibody (Millipore, Watford, UK) diluted at 1/2000 in PBSMB. Excess primary antibody was removed by washing twice in PBSMB buffer. A secondary antibody solution consisting of Alexa Fluor-488 goat-antimouse IgG antibody (Invitrogen) diluted at $1 / 1000$ in blocking buffer was added to each sample and incubated for $20 \mathrm{~min}$ at room temperature. Excess secondary antibody was removed by washing twice with PBSMB. Cells were finally resuspended in PBS for flow cytometry analysis. A minimum of 10,000 cells were analyzed using a FACS-BD-LSRII.

\section{Statistical Analysis}

Statistical analyses were performed using the $\mathrm{R}$ software. The two-way ANOVA statistical test was used to compare the interaction between the dose and the dose rate in order to determine the significance of the differences (a $p$-value $<0.05$ was considered statistically significant). The Student's $t$-test was also used to compare values between groups.

\section{RESULTS}

\section{Influence of Dose Rate Variation on HNSCC Radiosensitivity after High- and Low-LET Exposure}

Figure 1 shows the dose-response curves for cell killing induction in the radiosensitive SCC61 and radioresistant SQ20B cells after exposure to both carbon ion beams and photons. In response to photon irradiation, a significant change in the survival fraction at 2 Gy (SF2) and the dose for 10\% survival (D10) was observed for both cell lines depending on the dose rate. For SCC61 cells, the SF2 obtained after a $0.5 \mathrm{~Gy} / \mathrm{min}$ photon irradiation was 0.39 , whereas it significantly fell to 0.24 after a $2 \mathrm{~Gy} / \mathrm{min}$ and to 0.20 after a $10 \mathrm{~Gy} / \mathrm{min}$ irradiation. When statistical analysis was done, a significant difference $(p=0.02)$ between the three dose rate 
survival curves was observed. The same variation of the SF2 was observed for the radioresistant cell line SQ20B, where the SF2 value changed from 0.76 after a $0.5 \mathrm{~Gy} / \mathrm{min}$ photon irradiation to 0.71 after a $2 \mathrm{~Gy} / \mathrm{min}$ irradiation and to 0.50 after a $10 \mathrm{~Gy} / \mathrm{min}$ irradiation (Table 1). A significant difference $(p=0.04)$ between the different dose rate survival curves was also observed.

The survival curves realized after carbon ion irradiation were fitted either using simple linear or linear quadratic fit curves. Whatever the fit considered, and conversely to photon irradiation, dose rate changes in response to carbon ion irradiation did not affect the radiosensitivity. Whatever the radiosensitivity of the cells, the variation of the dose rate did not cause any change in cell survival, SF2, or D10 values. For SQ20B cells, the SF2 is 0.26 whatever the dose rate considered. For the SCC61 cell line,
SF2 varies from 0.09 to 0.07 depending on the dose rate $(p=0.21$ for the three survival curves with linear fit and $p=0.14$ for linear quadratic fit).

From these results, the $\mathrm{RBE}$ at $10 \%$ survival was calculated (Table 1). The RBE increased when the dose rate decreased both in the radiosensitive and radioresistant cell lines. For a dose rate of $0.5 \mathrm{~Gy} / \mathrm{min}$, RBE values are 2.1 and 2.0 for SCC61 and SQ20B cells, respectively; and they fall to 1.6 and 1.3 when a dose rate of $10 \mathrm{~Gy} / \mathrm{min}$ is applied.

\section{DNA Double-Strand-Break Analysis by $\gamma \mathrm{H} 2 \mathrm{AX}$ Flow Cytometry Assay}

Figures 2 and 3 show the $\gamma \mathrm{H} 2 \mathrm{AX}$ fluorescence for both cell lines after photon or carbon ion exposure reported to that of

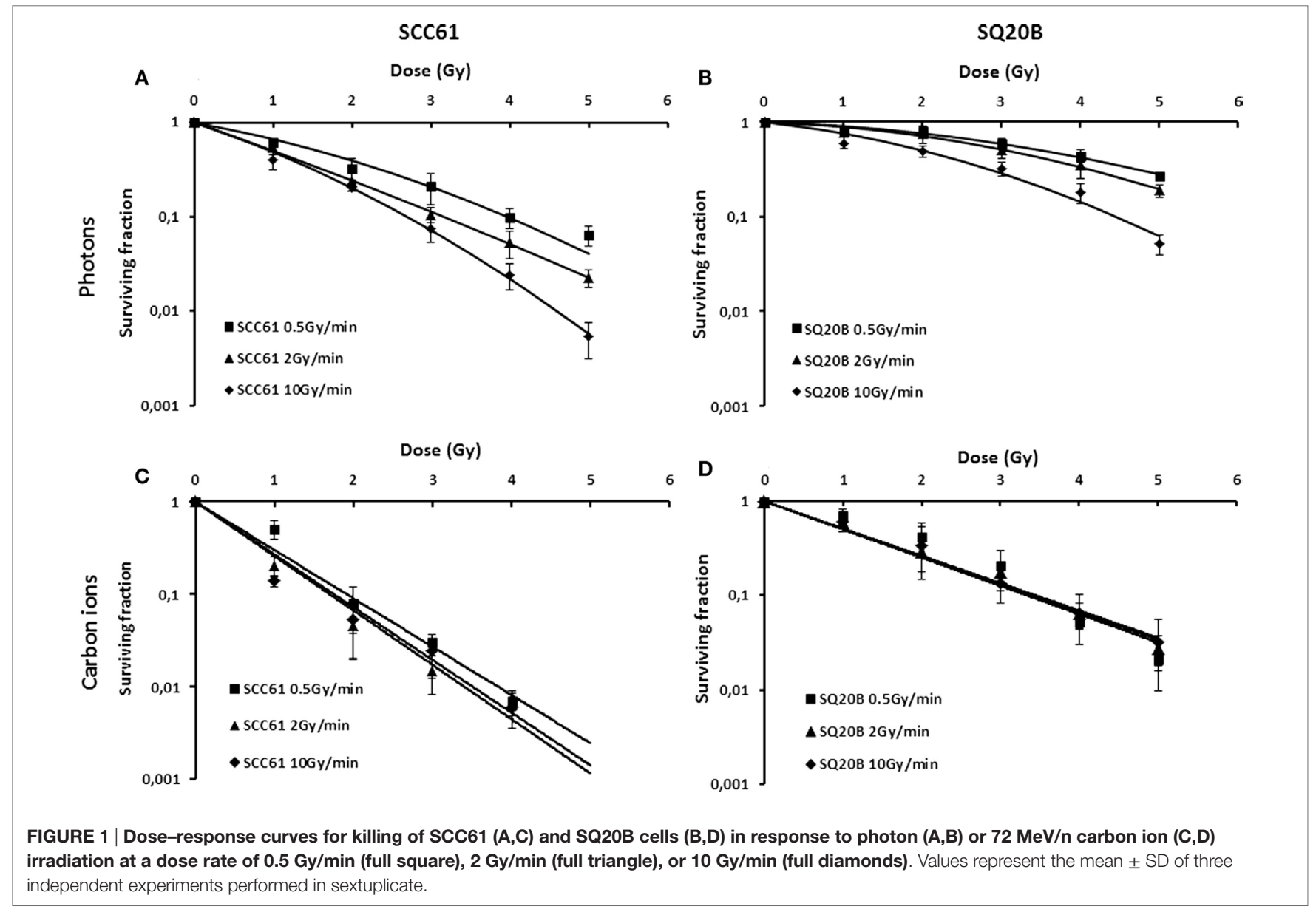

TABLE 1 | Radiobiological parameters of SCC61 and SQ20B cell lines for a 0.5, 2, or $10 \mathrm{~Gy} / \mathrm{min}$ photon or carbon ion irradiation.

\begin{tabular}{|c|c|c|c|c|c|c|}
\hline & Dose rate (Gy/min) & SF2 photons & SF2 carbon ions & D10 photons & D10 carbon ions & RBE \\
\hline SCC61 & 2 & 0.24 & 0.07 & 3.1 & 1.7 & 1.8 \\
\hline \multirow[t]{3}{*}{ SQ20B } & 0.5 & 0.76 & 0.26 & 6.9 & 3.4 & 2.0 \\
\hline & 2 & 0.71 & 0.26 & 6.0 & 3.4 & 1.8 \\
\hline & 10 & 0.50 & 0.26 & 4.4 & 3.4 & 1.3 \\
\hline
\end{tabular}

SF2, survival fraction at 2 Gy; D10, dose for $10 \%$ survival; RBE, relative biological effect of carbon ions at $10 \%$ survival. 
A

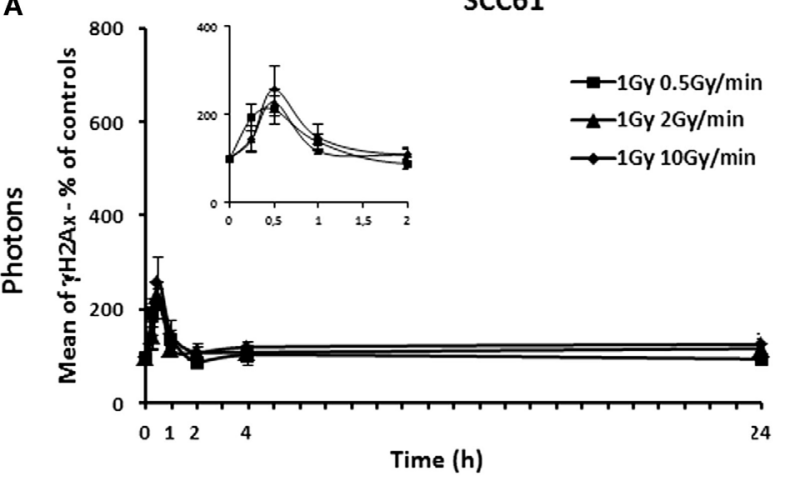

C

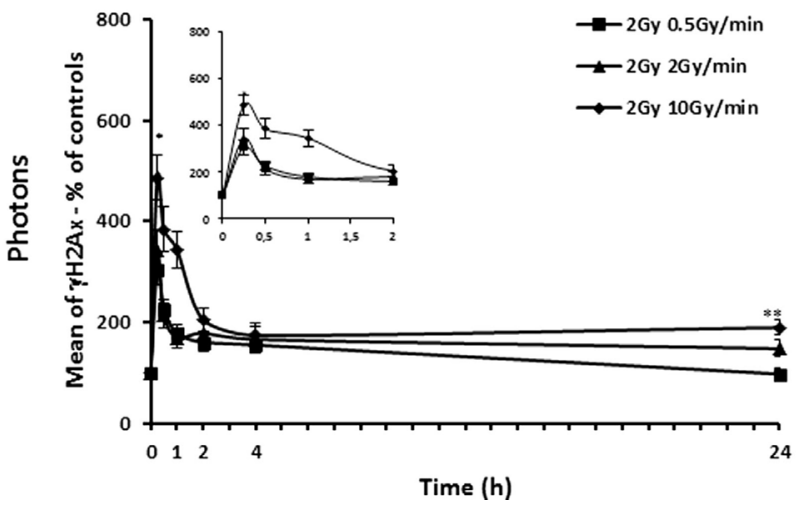

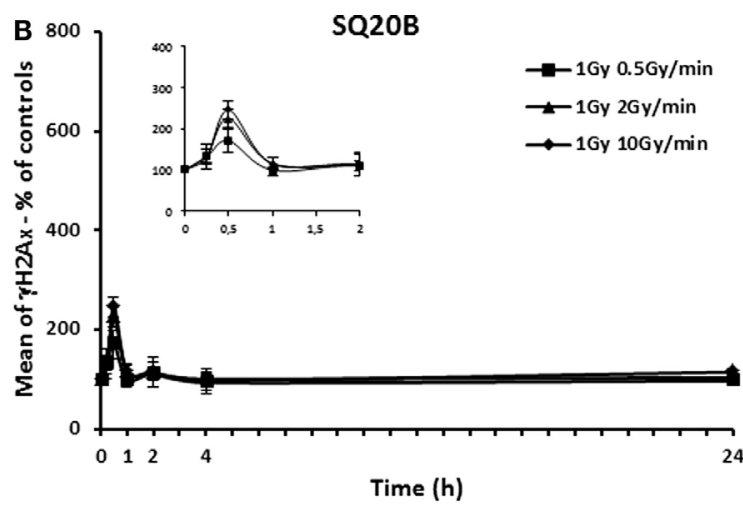

D

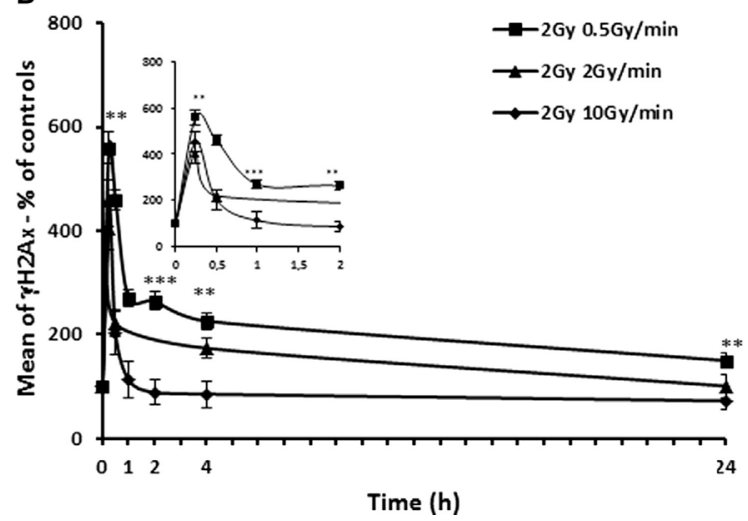

FIGURE $2 \mid$ Kinetic study of $\gamma$ H2AX foci. SCC61 (A,C) and SQ20B cells (B,D) were irradiated with 1 or 2 Gy photons at a dose rate of 0.5 Gy/min (full square), $2 \mathrm{~Gy} / \mathrm{min}$ (full triangle), or $10 \mathrm{~Gy} / \mathrm{min}$ (full diamonds). Short time points are represented in the insert. The percentage of $\gamma \mathrm{H} 2 \mathrm{AX}$ foci was calculated using sham-irradiated cells. For each time point, 10,000 cells were analyzed by flow cytometry. Values represent the mean \pm SD of one or two independent experiments performed in triplicate. ${ }^{*} p<0.05,{ }^{* *} p<0.01$, and ${ }^{\star \star *} p<0.001$.

A

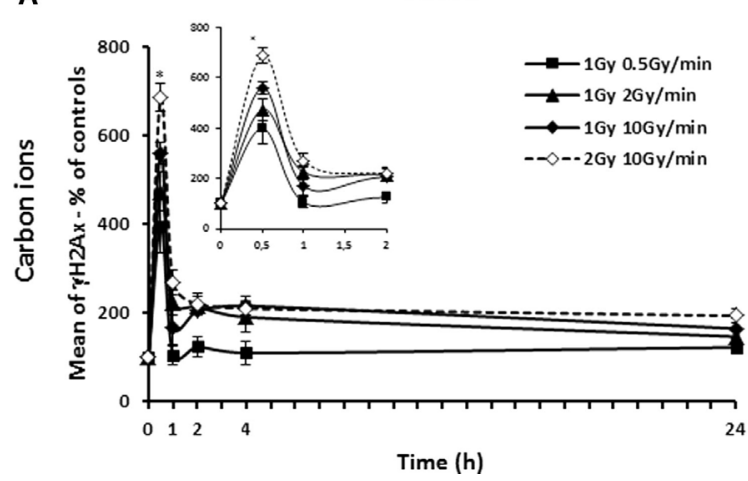

B

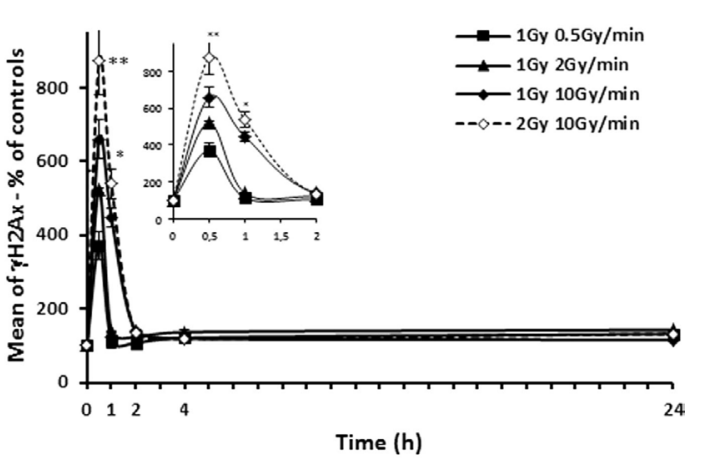

FIGURE 3 | Kinetic study of $\gamma$ H2AX foci. SCC61 (A) and SQ20B cells (B) were irradiated with 1 Gy carbon ions at a dose rate of 0.5 Gy/min (full square), $2 \mathrm{~Gy} / \mathrm{min}$ (full triangle), or $10 \mathrm{~Gy} / \mathrm{min}$ (full diamonds). A kinetic study at $10 \mathrm{~Gy} / \mathrm{min}$ for $2 \mathrm{~Gy}$ carbon ions is represented in dotted line. Short time points are represented in the insert. The percentage of $\gamma \mathrm{H} 2 \mathrm{AX}$ foci was calculated using sham-irradiated cells. For each time point, 10,000 cells were analyzed by flow cytometry. Values represent the mean \pm SD of two independent experiments performed in triplicate.

sham-irradiated controls. Different kinetic studies, from 15 min to $24 \mathrm{~h}$, were realized after 1 and 2 Gy photon or carbon ion exposure in order to compare the effect for the same physical dose (1 Gy photons compared to 1 Gy carbon ions and 2 Gy photons compared to 2 Gy carbon ions) as well as the effect for the same biological equivalent dose (1 Gy carbon ions compared to $2 \mathrm{~Gy}$ photons). The biological equivalent dose was calculated using an $\mathrm{RBE}$ of 2, previously calculated for a dose rate of $2 \mathrm{~Gy} / \mathrm{min}$ (12). 
At equivalent biological dose of photons and carbon ions, the initial peak of $\gamma \mathrm{H} 2 \mathrm{AX}$ foci, obtained $30 \mathrm{~min}$ after irradiation, was almost similar in both the radioresistant SQ20B and the radiosensitive SCC61 cells when the same dose rate was considered. At the opposite, for a same physical dose and a same dose rate, the initial peak for both cell lines was higher after a carbon ion irradiation compared with photon irradiation. However, whatever the dose or the type of irradiation is, the intensity of the peak depended on the dose rate. As an example, for the SQ20B cells, 30 min after 1 Gy of carbon ions, the percentage of $\gamma \mathrm{H} 2 \mathrm{AX}$ fluorescence was $370 \pm 39 \%$ compared to the sham-irradiated control for a dose rate of $0.5 \mathrm{~Gy} / \mathrm{min}$, $521 \pm 26 \%$ for $2 \mathrm{~Gy} / \mathrm{min}$, and $658 \pm 52 \%$ for $10 \mathrm{~Gy} / \mathrm{min}$. For all types of radiations and cells, the decrease of the amount in $\gamma \mathrm{H} 2 \mathrm{AX}$ took longer time for the higher dose rate. If we consider the residual double-strand breaks (DSBs) $24 \mathrm{~h}$ after irradiation, the results differed between the types of irradiation for both cell lines. Indeed, an effect of the dose rate was obtained after photon irradiation, whereas none was found after carbon ion irradiation (1 or 2 Gy). For both SCC61 and SQ20B irradiated with 2 Gy photons, a higher percentage of residual $\gamma \mathrm{H} 2 \mathrm{AX}$ fluorescence was found at a dose rate of $10 \mathrm{~Gy} / \mathrm{min}(190 \pm 15$ and $148 \pm 16 \%$, respectively) compared to $150 \pm 11$ and $98 \pm 12 \%$, respectively, when the dose rate decreases to $2 \mathrm{~Gy} / \mathrm{min}$. After a high-LET irradiation, the responses of both cell lines were different. For the radiosensitive cells, the residual number of DNA DSBs varied between $165 \pm 23$ and $123 \pm 13 \%$ after 10 and $0.5 \mathrm{~Gy} / \mathrm{min}$, respectively, but this variation was not statistically significant. For the radioresistant cell line, the percentage of residual $\gamma \mathrm{H} 2 \mathrm{AX}$ foci was lower, between $132 \pm 11$ and $115 \pm 3$ for 10 and $0.5 \mathrm{~Gy} /$ min, respectively, and also not significant.

\section{DISCUSSION}

Our study demonstrates that a variation in the dose rate affects cell survival only for low-LET irradiation and that this variation does not depend on the initial radiosensitivity of the cell line considered. Although the effects of an important dose rate variation (gray per second to gray per hour) after low-LET radiation has been reported for several years (16), very few studies related these effects in regard to the intensity-modulated RT techniques or in response to high-LET irradiation. Therefore, the aim of our work was to study the effect of a dose rate variation during high- or low-LET irradiations in terms of cell survival and DNA DSB repair. Our study was realized using two HNSCC cell lines displaying opposite radiosensitivity, irradiated with photons or carbon ions at dose rates of $0.5,2$, or $10 \mathrm{~Gy} / \mathrm{min}$. These dose rates correspond to an irradiation time varying from $15 \mathrm{~s}$ to $20 \mathrm{~min}$, matching with the irradiation duration associated with the active ion beam techniques, on one hand, and, to the sessions of multifield irradiation, on the other hand.

First of all, we confirmed previous data $(16,17)$ demonstrating that even with a very slight change in the dose rate of photon, a variation of radiosensitivity (SF2 and D10) was observed. Moreover, this variation does not depend on the intrinsic radiosensitivity. In response to photon irradiation, it has been previously reported that a significant reduction in the lethality, mutagenesis, and carcinogenesis was observed when the dose is delivered at low dose rates compared to high dose rates [for review, see Ref. (18)]. The advanced hypothesis to explain these results was that damage spreads more over a time at a low dose rate, which should allow cells to have more time to detect DNA damages and activate their repair systems (19). Our results obtained for both cell lines confirm this hypothesis and are in total accordance with our previous published study (20), which reported that more initial and residual $\gamma \mathrm{H} 2 \mathrm{AX}$ foci were found after photon irradiation. Boucher et al. (21) have also demonstrated that low-LET radiation-induced lethality at low dose rate was accompanied by a decreased number of DSBs. They have additionally highlighted the involvement of the non-homologous end joining pathway in the repair of gamma-induced DSBs at $20 \mathrm{mGy} / \mathrm{min}$. The impact of the dose rate was also studied on the induction of apoptotic cell death. In lymphocyte, it appears that only a very low dose rate has an effect on the induction of apoptosis (22). This is of particular interest in head and neck locations, where intensity-modulated techniques are used, and dose rate variations are observed in the different planned beams. Since static intensity-modulated-RT is the gold standard for head and neck RT (23), this technique increases the treatment time compared to $3 \mathrm{D}$ conformational RT. Volumetric modulated arc therapy has thus been developed and reduced by $50 \%$ treatment time (24). This technique can limit intrafraction patients' movements and maintain an acceptable dose rate through the decreased treatment time. In our study, dose rate influence in photon irradiation suggests that the radiation therapist has to take it into account when choosing the planning technique.

As no data, obtained in the same conditions, are up to now available with high-LET, the second important aim of this study was to evaluate the influence of a high-LET dose rate variation on HNSCC cells. We demonstrated that, in contrast to photon irradiation, a carbon ion dose rate variation did not significantly affect cell survival irrespective of whatever the intrinsic radio sensitivity of the cell line used. As a consequence, we have demonstrated that the RBE at $10 \%$ survival increased when the dose rate decreased. Our results are in accordance with Masunaga et al. (25) who have studied the RBE of $290 \mathrm{MeV} / \mathrm{n}$ carbon ions, a LET found in the healthy tissues, by changing only the photon dose rate in quiescent tumor cells. Unlike us, the LET used in this study correspond to that found at the beginning of the SOBP. In order to confirm our results, it would now be of great interest to test the influence of a dose rate variation with a higher LET corresponding to that found in the center of the tumor. Moreover, as experiments were done only in tumor cells, it would be essential to study the response of healthy tissue surrounding the tumor.

We also evaluated DNA damage in our work. Although there is a slight effect on initial DNA DSBs 30 min after carbon ion irradiation, depending on the dose rate, no difference was observed on the residual ones. It is now well established that a localized deposition of high-LET particle results in complex DNA DSBs that cause cell death, mutations, and genomic instability (20, 26). By contrast, the repair mechanisms of high-LET-induced DSBs are not fully understood (27). From our results, we can assume that the DNA damage response processes seems to be different between photon and carbon ion irradiation and then 
complementary experiments need to be done, in order to explain why there is no effect of the dose rate on cell survival after highLET irradiation.

In conclusion, this study was carried out to understand whether a variation of the dose rate during a photon altered fractionation, intensity-modulated-RT, or a hadrontherapy treatment could affect cell survival or not. This study was of crucial interest since during hadrontherapy there is an important variation of the dose rate occurring within the tumor and since the adaptation of current HNSCC RT treatment schemes and techniques is still performed empirically. Thus, we have shown that in response to photon exposure, the change in dose rate significantly affected cell survival for both radiosensitive and radioresistant cells, this variation of radiosensitivity was directly correlated to the number of initial and residual DNA DSBs. By contrast, the dose rate change did not affect neither cell survival nor the residual DNA DSBs after carbon ion irradiation.

\section{REFERENCES}

1. Bray F, Ferlay J, Laversanne M, Brewster DH, Gombe Mbalawa C, Kohler B, et al. Cancer incidence in five continents: inclusion criteria, highlights from volume $\mathrm{X}$ and the global status of cancer registration. Int J Cancer (2015) 137:2060-71. doi:10.1002/ijc.29670

2. Argiris A, Karamouzis MV, Raben D, Ferris RL. Head and neck cancer. Lancet (2008) 371:1695-709. doi:10.1016/S0140-6736(08)60728-X

3. Vermorken JB, Remenar E, van Herpen C, Gorlia T, Mesia R, Degardin M, et al. Cisplatin, fluorouracil, and docetaxel in unresectable head and neck cancer. N Engl J Med (2007) 357:1695-704. doi:10.1056/NEJMoa071028

4. Posner MR, Hershock DM, Blajman CR, Mickiewicz E, Winquist E, Gorbounova V, et al. Cisplatin and fluorouracil alone or with docetaxel in head and neck cancer. N Engl JMed (2007) 357:1705-15. doi:10.1056/ NEJMoa070956

5. Grégoire V, LangendijkJA, Nuyts S. Advances in radiotherapy for head and neck cancer. J Clin Oncol (2015) 33(29):3277-84. doi:10.1200/JCO.2015.61.2994

6. Bourhis J, Overgaard J, Audry H, Ang KK, Saunders M, Bernier J, et al. Hyperfractionated or accelerated radiotherapy in head and neck cancer: a meta-analysis. Lancet (2006) 368:843-54. doi:10.1016/S0140-6736(06)69121-6

7. van Beek KM, Kaanders JHAM, Janssens GO, Takes RP, Span PN, Verhoef CG. Effectiveness and toxicity of hypofractionated high-dose intensity-modulated radiotherapy versus 2 - and 3-dimensional radiotherapy in incurable head and neck cancer. Head Neck (2015). doi:10.1002/hed.24203

8. Held KD, Kawamura H, Kaminuma T, Paz AES, Yoshida Y, Liu Q, et al. Effects of charged particles on human tumor cells. Radiat Oncol (2016) 6:23. doi:10.3389/fonc.2016.00023

9. Loeffler JS, Durante M. Charged particle therapy - optimization, challenges and future directions. Nat Rev Clin Oncol (2013) 10:411-24. doi:10.1038/ nrclinonc.2013.79

10. Weichselbaum RR, Dahlberg W, Beckett M, Karrison T, Miller D, Clark J, et al. Radiation-resistant and repair-proficient human tumor cells may be associated with radiotherapy failure in head- and neck-cancer patients. Proc Natl Acad Sci U S A (1986) 83:2684-8. doi:10.1073/pnas.83.8.2684

11. Alphonse G, Maalouf M, Battiston-Montagne P, Ardail D, Beuve M, Rousson $\mathrm{R}$, et al. p53-independent early and late apoptosis is mediated by ceramide after exposure of tumor cells to photon or carbon ion irradiation. BMC Cancer (2013) 13:151. doi:10.1186/1471-2407-13-151

12. Beuve M, Alphonse G, Maalouf M, Colliaux A, Battiston-Montagne $\mathrm{P}$, Jalade P, et al. Radiobiologic parameters and local effect model predictions for head-and-neck squamous cell carcinomas exposed to high linear energy transfer ions. Int J Radiat Oncol Biol Phys (2008) 71:635-42. doi:10.1016/j. ijrobp.2007.10.050

\section{AUTHOR CONTRIBUTIONS}

Substantial author contributions: to the conception or design of the work: GA, MB, and CR-L; to the acquisition: GA, A-SW, PB-M, SS, and ET; to the analysis: GA, A-SW, and J-BG; to the interpretation: DP, A-SW, GA, CR, CR-L, and MB; and to the final approval of the manuscript: NM and CR-L.

\section{ACKNOWLEDGMENTS}

We thank everyone who participated in the experiments at GANIL and particularly the CIRIL's and LARIA's teams. We acknowledge the contribution of the flow cytometry platform of the SFR BioSciences-Gerland-Lyon-Sud (UMS3444/US8) and Lyric INCa-DGOS-4664. This work was financed by EDF and by the Contrat Plan-Etat-Region within the scientific framework of ETOILE. It was also supported by France Hadron (ANR-11INBS-0007) and Labex Primes (ANR-11-LABX-0063).

13. Durantel F, Balanzat E, Cassimi A, Chevalier F, Ngono-Ravache Y, Madi T, et al. Dosimetry for radiobiology experiments at GANIL. Nucl Instrum Methods Phys Res A (2016) 816:70-7. doi:10.1016/j.nima.2016.01.052

14. Maalouf M, Alphonse G, Colliaux A, Beuve M, Trajkovic-Bodennec S, Battiston-Montagne $\mathrm{P}$, et al. Different mechanisms of cell death in radiosensitive and radioresistant p53 mutated head and neck squamous cell carcinoma cell lines exposed to carbon ions and x-rays. Int J Radiat Oncol Biol Phys (2009) 74:200-9. doi:10.1016/j.ijrobp.2009.01.012

15. Tanaka T, Halicka D, Traganos F, Darzynkiewicz Z. Cytometric analysis of DNA damage: phosphorylation of histone $\mathrm{H} 2 \mathrm{AX}$ as a marker of DNA double-strand breaks (DSBs). Methods Mol Biol (2009) 523:161-8. doi:10.1007/978-1-59745-190-1_11

16. Hall EJ. Radiation dose-rate: a factor of importance in radiobiology and radiotherapy. Br J Radiol (1972) 45:81-97. doi:10.1259/0007-1285-45-530-81

17. Appelbaum FR. The influence of total dose, fractionation, dose rate, and distribution of total body irradiation on bone marrow transplantation. Semin Oncol (1993) 20:3-10.

18. Marples B, Collis SJ. Low-dose hyper-radiosensitivity: past, present, and future. Int J Radiat Oncol Biol Phys (2008) 70:1310-8. doi:10.1016/j. ijrobp.2007.11.071

19. Núñez MI, McMillan TJ, Valenzuela MT, Ruiz de Almodóvar JM, Pedraza V. Relationship between DNA damage, rejoining and cell killing by radiation in mammalian cells. Radiother Oncol (1996) 39:155-65. doi:10.1016/0167-8140(96)01732-X

20. Hanot M, Boivin A, Malésys C, Beuve M, Colliaux A, Foray N, et al. Glutathione depletion and carbon ion radiation potentiate clustered DNA lesions, cell death and prevent chromosomal changes in cancer cells progeny. PLoS One (2012) 7:e44367. doi:10.1371/journal.pone.0044367

21. Boucher D, Hindo J, Averbeck D. Increased repair of gamma-induced DNA double-strand breaks at lower dose-rate in CHO cells. Can J Physiol Pharmacol (2004) 82:125-32. doi:10.1139/y04-006

22. Boreham DR, Dolling JA, Maves SR, Siwarungsun N, Mitchel RE. Dose-rate effects for apoptosis and micronucleus formation in gamma-irradiated human lymphocytes. Radiat Res (2000) 153:579-86. doi:10.1667/0033-7587(2000)15 3[0579:DREFAA] 2.0.CO;2

23. O'Sullivan B, Rumble RB, Warde P; Members of the IMRT Indications Expert Panel. Intensity-modulated radiotherapy in the treatment of head and neck cancer. Clin Oncol (R Coll Radiol) (2012) 24:474-87. doi:10.1016/j. clon.2012.05.006

24. Holt A, Van Gestel D, Arends MP, Korevaar EW, Schuring D, Kunze-Busch $\mathrm{MC}$, et al. Multi-institutional comparison of volumetric modulated arc therapy vs. intensity-modulated radiation therapy for head-and-neck cancer: a planning study. Radiat Oncol (2013) 8:26. doi:10.1186/1748-717X-8-26 
25. Masunaga S-I, Ando K, Uzawa A, Hirayama R, Furusawa Y, Koike S, et al. Radiobiologic significance of response of intratumor quiescent cells in vivo to accelerated carbon ion beams compared with gamma-rays and reactor neutron beams. Int J Radiat Oncol Biol Phys (2008) 70:221-8. doi:10.1016/j. ijrobp.2007.09.021

26. Prise KM, Pinto M, Newman HC, Michael BD. A review of studies of ionizing radiation-induced double-strand break clustering. Radiat Res (2001) 156:572-6. doi:10.1667/0033-7587(2001)156[0572:AROSOI]2.0.CO;2

27. Hada M, Georgakilas AG. Formation of clustered DNA damage after high-LET irradiation: a review. J Radiat Res (2008) 49:203-10. doi:10.1269/ jrr.07123
Conflict of Interest Statement: The authors declare that the research was conducted in the absence of any commercial or financial relationships that could be construed as a potential conflict of interest.

Copyright ( 2016 Wozny, Alphonse, Battiston-Montagne, Simonet, Poncet, Testa, Guy, Rancoule, Magné, Beuve and Rodriguez-Lafrasse. This is an open-access article distributed under the terms of the Creative Commons Attribution License (CC BY). The use, distribution or reproduction in other forums is permitted, provided the original author(s) or licensor are credited and that the original publication in this journal is cited, in accordance with accepted academic practice. No use, distribution or reproduction is permitted which does not comply with these terms. 